JED

23,2

116

Received 22 September 2020 Revised 20 December 2020 Accepted 8 February 2021

\section{Re-examining the impact of financial intermediation on economic growth: evidence from Turkey}

\author{
Ibrahim Nandom Yakubu, Aziza Hashi Abokor and Iklim Gedik Balay \\ Department of Banking and Finance, Ankara Yildirim Beyazit University, \\ Ankara, Turkey
}

\begin{abstract}
Purpose - This study seeks to investigate the impact of financial intermediation on economic growth in Turkey using annual data spanning 1970-2017.

Design/methodology/approach - Based on the results of the augmented Dickey-Fuller and PhillipsPerron unit root tests for stationarity, the authors employ the Autoregressive Distributed Lag (ARDL) bounds testing to cointegration to establish the long-run impact of financial intermediation alongside other control factors on economic growth. The study also examines the short-run relationship between financial intermediation and economic growth by estimating the Error Correction Model (ECM).

Findings - The authors' findings indicate that financial intermediation significantly influences economic growth in both short and long run. However, the effect is positive only in the short run, lending support to the supply-leading hypothesis. Regarding the control variables, the authors observe that while financial openness shows a positive significant impact on economic growth in the long run, gross fixed capital formation matters only in the short run. The results further infer that regardless of the time period, inflation impedes economic growth.

Originality/value - In the empirical analysis of the relationship between financial intermediation and economic growth, financial intermediation is always measured using a single variable. The authors argue that such studies could produce bias and misleading results given that a single proxy does not adequately reflect financial intermediation activities. Likewise, such findings may delude policy implementation. To provide a more vivid and robust analysis, the authors employ the Principal Component Analysis (PCA) to construct a composite index for financial intermediation based on three broad measures. The researchers' are unaware of any study on the financial intermediation-economic growth nexus using a composite index of financial intermediation. Thus, this paper fills this lacuna in the literature.
\end{abstract}

Keywords Financial intermediation, Economic growth, ARDL framework, Turkey

Paper type Research paper

\section{Introduction}

In every economy, financial resources are pertinent for enhancing growth through efficient financial intermediation (Sulaiman and Aluko, 2015). Financial intermediaries particularly banks play a crucial role in a country's overall financial system by embarking on several activities vital for economic growth (Aziakpono, 2005; Ünvan and Yakubu, 2020). For instance, financial intermediaries serve as a conduit by which financial resources move from surplus to deficit economic units. They aid in maturity transformation, thus ensuring sufficient liquidity.

\section{JEL Classification - G10, G21, O11}

(C) Ibrahim Nandom Yakubu, Aziza Hashi Abokor and Iklim Gedik Balay. Published in Journal of Economics and Development. Published by Emerald Publishing Limited. This article is published under the Creative Commons Attribution (CC BY 4.0) licence. Anyone may reproduce, distribute, translate and create derivative works of this article (for both commercial and non-commercial purposes), subject to full attribution to the original publication and authors. The full terms of this licence may be seen at http:// creativecommons.org/licences/by/4.0/legalcode

The authors are grateful to the anonymous reviewers for their comments on the manuscript.
Journal of Economics and Development Vol. 23 No. 2,2021 pp. 116-127

Emerald Publishing Limited e-ISSN: 2632-5330

p-ISSN: $1859-0020$

DOI 10.1108/JED-09-2020-0139 
Financial intermediaries also ensure risk management by providing mechanisms for diversification and risk-sharing.

Efficient financial intermediation as opined by Agbada and Osuji (2013) creates a lively financial system, improves employment and output level, as well as income. Greenwood and Jovanovic (1990) argued that through financial intermediation, individuals and firms earn higher returns on investment, contributing to economic well-being. According to McKinnon (1973) and Shaw (1973), economic growth is mainly driven by financial intermediation. They both infer that investment level influenced by growth in savings directly affects economic growth. A surge in savings triggers more investments, which increase capital formation rate, with a consequent positive impact on economic growth. Conversely, finance can sometimes inhibit economic growth. King and Levine (1993) argued that the financial system may experience a sluggish development with a subsequent effect on economic growth as a result of certain constraints imposed on the banking system by the government. For instance, high mandatory reserves and interest rate ceilings may hurt the competitiveness of the financial sector.

For the past decades, the effect of financial intermediation on economic growth has received significant research attention. Nevertheless, the link between these variables remains unsettled. While some studies established that financial intermediation matters for economic growth (see Ventura, 2008; Murty et al., 2012; Sahoo, 2014; Türsoy and Faisal, 2018), others evidenced an inimical impact of finance on growth (Acha, 2011; Zaghdoudi et al., 2013; Sulaiman and Aluko, 2015; John and Nwekemezie, 2019). Despite the pool of research on the subject matter, studies in Turkey (for instance, Kar et al., 2008; Yucel, 2009; Demirhan et al., 2011; Kapusuzoglu, 2013; Ak et al., 2016) focus largely on examining the impact of financial development on growth using the notable "bank credit to private sector" as a proxy of financial development. How the other facets of financial intermediation (e.g. deposit and money supply) affect growth is scarcely discussed. Consequently, we seek to contribute to the global debate on financial intermediation-growth nexus in the context of Turkey.

Undoubtedly, extant studies are largely based on single proxies of financial intermediation. The most commonly employed individual indicators include broad money, credit to private sector, savings, interest rates and so on. Using a single measure is quite narrowed and does not fully reflect financial intermediation activities. To differ from prior studies and to provide a more comprehensive analysis, we construct an index of financial intermediation relying on three broad indicators (broad money, bank deposit and domestic credit by the financial sector).

We contribute to the financial intermediation-economic growth literature in two ways. First, we are unaware of any existing study employing an index of financial intermediation to investigate its impact on economic growth, particularly in Turkey. Thus, we present a pioneering attempt in this context. Apart from this, we seek to examine the short- and longrun impact of financial intermediation on economic growth by applying the autoregressive distributed lag (ARDL) framework on recent data.

The paper is further organized as follows: Section 2 presents the literature review. Section 3 outlines our data and analytical strategy. Section 4 discusses the findings, and Section 5 concludes with implications.

\section{Literature review}

The seminal work of Patrick (1966) examined the finance-economic growth relationship in terms of supply-leading hypothesis and demand-following hypothesis. For the supplyleading hypothesis, the pivotal argument is that economic growth is caused by financial deepening. It postulates that financial sector development leads to optimal resource allocation (Hurlin and Venet, 2008). A developed and sound financial sector creates financial services and provides easy access to these services in anticipation to the demand for them by 
JED

23,2

118

economic units. The supply-leading hypothesis infers that the economy rapidly responds to real sector growth driven by the development of the financial sector. The demand-following hypothesis, on the other hand, presumes that financial development is induced by economic growth. The growth in the real economy spurs the demand for financial services leading to the creation and improvement of financial institutions to meet the increasing demand for these services (Demetriades and Hussein, 1996).

At the empirical front, the effect of financial intermediation on economic growth has been investigated at both cross-country and country-specific level with inconclusive findings. For instance, in a cross-country analysis, Levine et al. (2000) investigated the impact of financial intermediation on economic growth using data of 71 countries while applying different panel approaches. The authors found that economic growth is positively driven by financial intermediation across countries. Using West African countries within the Economic Community of West African States (ECOWAS), Atindéhou et al. (2005) empirically assessed the relationship between financial intermediation and economic growth. Results from the panel vector autoregressive (VAR) model showed that for most of the sampled countries, financial intermediation has a direct impact on economic growth. In a multicountry analysis, Adusei and Afrane (2013) assessed how the intermediation of credit unions impacts on economic growth. Applying the generalized method of moments panel technique on data spanning 1995-2011, the authors established a significant positive impact of financial intermediation on economic growth. Employing data of 28 countries for the period 2001-2010 in both developed and developing countries, Bogdan and Opris (2013) applied different econometric approaches to evaluate the impact of financial intermediation on economic growth. Using different measures of intermediation, the authors generalized that growth is positively driven by the level of financial intermediation. Contrary to the positive effect of intermediation, Zaghdoudi et al. (2013) found that banking intermediation negatively affects economic growth in the Middle East and North Africa (MENA) countries.

At the country-specific level, Ventura (2008) investigated how financial intermediation affects economic growth in Colombia. Using the ARDL approach, the author established a positive significant impact of intermediation on economic growth in both short- and long-run periods. Murty et al. (2012) assessed the long-run effect of financial intermediation on growth in Ethiopia using the Johansen cointegration approach. The results revealed that bank credit to private sector as an indicator of financial intermediation exerts a positive significant longrun effect on economic growth. Invoking the VAR technique, Amaira and Amairya (2014) reported that financial intermediation has a positive impact on economic growth in Tunisia. Sahoo's (2014) Granger causality test evidenced that economic growth in India is driven positively by financial intermediation. Türsoy and Faisal (2018) using the ARDL model showed that economic growth is influenced by deposit growth (a measure of financial depth) in Cyprus. In contrast to the preceding results, Acha (2011) evidenced no direct impact of financial intermediation on economic growth in Nigeria. Similarly, Sulaiman and Aluko (2015) and John and Nwekemezie (2019) found that financial intermediation does not motivate growth in Nigeria.

From the literature review, the financial intermediation-economic growth relationship remains unsettled as findings differ at both country-level and cross-country studies. We seek to contribute to the inconclusive debate by assessing how financial intermediation affects growth in Turkey.

\section{Methodology}

\subsection{Data and sources}

In this study, we use annual data covering the period 1970-2017. Our main independent variable is financial intermediation. We control for the effect of financial openness, gross 
fixed capital formation and inflation on growth. Data for all the variables except for financial openness are sourced from the World Development Indicators of the World Bank. The data for financial openness is gleaned from the Chinn and Ito Financial Openness Index.

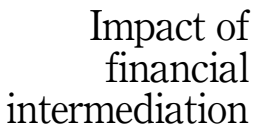

\subsection{Description of variables}

3.2.1 Economic growth (GDPG). Economic growth serves as the dependent variable. This is measured by gross domestic product (GDP) per capita.

3.2.2 Financial intermediation (FINT). We construct an index of financial intermediation based on three measures (broad money, bank deposit and domestic credit by the financial sector) using the Principal Component Analysis (PCA). These indicators are chosen given their significance in the literature. The effect of financial intermediation on growth is inconclusive, hence a positive or a negative relationship is expected.

3.2.3 Financial openness (FOP). The KAOPEN index by Chinn and Ito is employed as a proxy of financial openness. According to economic theory, economic growth should be positively influenced by financial openness (Estrada et al., 2015). Countries that are opened to the global markets experience more capital flows. The inflows of foreign direct investment (FDI) can drive economic growth through several channels such as advanced technology, competitiveness in the domestic market and managerial skills. Given this, we expect financial openness to positively correlate with economic growth.

3.2.4 Gross fixed capital formation (GFCF). GFCF indicates domestic investment. Keynes posits that a country's aggregate demand is boosted by domestic investments (Tobin, 1965). A boom in domestic investment is expected to create more employment opportunities and enhance output. Theoretically, domestic investment and economic growth exhibit a bidirectional relationship. Prior studies have demonstrated a positive effect of domestic investment on economic growth (Bakare, 2011; Kanu and Ozurumba, 2014; Ncanywa and Makhenyane, 2016). Given the aforementioned premise, we hypothesize a positive influence of GFCF on economic growth.

3.2.5 Inflation (INF). Inflation is measured by consumer prices (annual percentage). In the literature, the relationship between inflation and economic growth is inconclusive (i.e. a positive, negative and sometimes neutral relationship). Given that an increasing level of inflation is associated with a high cost of living where investable resources are channeled to consumption, we expect inflation to decrease growth.

\subsection{Model specification}

To analyze the effect of financial intermediation and the control variables on economic growth, the empirical model following the work of Levine et al. (2000) is clearly presented as:

$$
\mathrm{GDPG}_{t}=\alpha_{0}+\beta_{1} \mathrm{FINT}_{t}+\beta_{2} \mathrm{FOP}_{t}+\beta_{3} \mathrm{GFCF}_{t}+\beta_{4} \mathrm{INF}_{t}+\varepsilon_{t}
$$

where GDPG, FINT, FOP, GFCF and INF are explained previously. $\varepsilon$ and $t$ denote the error term and sample period, respectively. $\alpha_{0}$ represents the intercept, and $\beta_{1}$ to $\beta_{4}$ connote the coefficients of the independent variables.

\subsection{Analytical approach}

We seek to examine the short-run and long-run impact of financial intermediation on economic growth while controlling for the effect of other factors. The study employs the ARDL model by Pesaran and Shin (1998) and Pesaran et al. (2001). The ARDL model is applicable in different contexts, rendering it advantageous over other methods. For instance, the model is suitable for studies with a small sample size. It also takes on variables that are stationary at different levels. Under this model, variables can assume different lag lengths. 
JED

23,2

120

To investigate the long-run and short-run effect of our variables on economic growth, the ARDL model is specified as:

$$
\begin{aligned}
\mathrm{GDPG}_{t}= & \alpha_{0}+\sum_{i=0}^{n} \alpha_{1 i} \Delta \mathrm{GDPG}_{t-1}+\sum_{i=0}^{n} \alpha_{2 i} \Delta \mathrm{FINT}_{t-1}+\sum_{i=0}^{n} \alpha_{3 i} \Delta \mathrm{FOP}_{t-1} \\
& +\sum_{i=0}^{n} \alpha_{4 i} \Delta \mathrm{GFCF}_{t-1}+\sum_{i=0}^{n} \alpha_{5 i} \Delta \mathrm{INF}_{t-1}+\delta_{1} \mathrm{GDPG}_{t-1}+\delta_{2} \mathrm{FINT}_{t-1} \\
& +\delta_{3} \mathrm{FOP}_{t-1}+\delta_{4} \mathrm{GFCF}_{t-1}+\delta_{5} \mathrm{INF}_{t-1}+\rho \mathrm{ECT}_{t-1}+\varepsilon_{t}
\end{aligned}
$$

where $\alpha_{0}$ is the intercept; $\Delta$ denotes the difference operator; $\alpha_{1}-\alpha_{5}$ and $\delta_{1}-\delta_{5}$ are short-run and long-run coefficients, respectively; $\varepsilon$ is the error term; $n$ is the lag length; $\rho$ is the coefficient of ECT, where $\mathrm{ECT}_{t-1}$ symbolizes the error correction term lagged by one period.

We perform a bound testing to examine the long-run relationship among the variables. In doing so, the null hypothesis that specifies there is no long-run relationship among the variables is tested against the alternative hypothesis as follows:

$$
\begin{gathered}
H_{0}: \delta_{1}=\delta_{2}=\delta_{3}=\delta_{4}=\delta_{5}=0 \\
H_{1}: \text { At least one } \delta i \neq 0, i=1,2,3,4,5
\end{gathered}
$$

To test for the existence of cointegration, we use the two critical bounds, the upper and lower bounds. A long-run relationship is established when the $F$-statistics is greater than the upper critical bound I(1), and no cointegration is assumed when the $F$-statistics is less than the lower bound critical value $\mathrm{I}(0)$.

\subsection{Principal Component Analysis (PCA)}

The study reduces the dimensions of the financial intermediation variables into principal components that are linearly uncorrelated. Generally, the PCA is a data analysis tool that is normally adopted to reduce the dimensionality - number of variables of a large number of interrelated variables, while retaining as much information - variations as possible. PCA calculates an uncorrelated set of variables - Principal Components (PCs). These factors are ordered in a manner that the first few principally composed factors preserve most of the variations present in all of the original variables (Hardle and Simar, 2015).

The aim of PCA is to identify $k<n$ (usually $k=2$ or 3 ) new variables that will turn out to be the PCs that determine a large portion of the information stored in the data by accounting for the highest covariations possible in it (Abdi and Williams, 2010). The transformations in the data set are defined in a way such that the preceding PC has the leading possible variance and subsequent components in turn have the highest variance possible in that order, under the constraint that they are all orthogonal or uncorrelated with preceding components (Jolliffe, 2002). PCs are orthogonal or uncorrelated because they are the eigenvectors of the covariance matrix, which is symmetric (Sharma, 1996).

Based on the selected financial intermediation variables (broad money, bank deposit and domestic credit by the financial sector), according to this PCA technique, the $j$ th factor index can be specified as:

$$
\mathrm{FINT}_{j}=W_{J 1} X_{1}+W_{J 2} X_{2}+W_{J 3} X_{3}+\ldots+W_{J P} X_{P}
$$

where $\mathrm{FINT}_{j}$ is the Financial Intermediation Index; $W_{j}$ is the weight of the parameter of the factor score; $X$ is the original figure of the respective components; while $P$ is the number of variables in the equation. 


\section{Empirical results}

4.1 Descriptive statistics and correlation analysis

In Table 1, the descriptive statistics and the correlation matrices for all the variables are presented. GDP per capita growth, a proxy of economic growth, has a mean value of $2.76 \%$ ranging from $-7.36 \%$ to $9.42 \%$. Inflation has the highest SD indicating higher volatility. Economic growth and capital formation show a negative skewness with the rest of the factors being positively skewed. As depicted by the Jarque-Bera probability values, we observe that the variables are normally distributed at $5 \%$ except for financial intermediation. Table 1 further illustrates that there is no multicollinearity issue in our study given that the variables have weak correlation coefficients based on the 0.80 correlation threshold recommend by Kennedy (2003). To further verify the nonexistence of multicollinearity, we conduct the variance inflation factor (VIF) analysis. The VIF analysis specifies that for variables to be free from multicollinearity problems, they must show a VIF value below 10 and the tolerance value exceeding 0.10 . Our analysis satisfies these presumptions.

\subsection{Unit root tests}

From Table 2, the unit root test results based on the Augmented Dickey-Fuller (ADF) and Phillips-Perron (PP) are presented. For both ADF and PP tests, GDP per capita growth shows stationarity at level $(\mathrm{I}(0))$ at $1 \%$ level of significance. The rest of our variables become stationary at first difference (I(1)) at 1\% significance level for both tests. Given the mixed results, our study fulfills the preconditions for the application of the ARDL model.

\subsection{Bounds testing for cointegration}

From the bounds-testing results in Table 3 , the $F$-statistics is greater than the upper critical bound value at $1 \%$ significance level. This signifies the existence of cointegration among our variables. Hence, we estimate the long-run relationship between economic growth and our independent factors relying on the Akaike Information Criterion (AIC).

\subsection{Long-run estimation}

We present the long-run estimates in Table 4. Our results evidence a significant negative impact of financial intermediation on economic growth. This suggests that banks'

\begin{tabular}{lrrrrr}
\hline & GDPG [1] & FINT [2] & FOP [3] & GFCF [4] & INF [5] \\
\hline Mean & 2.755 & 0.851 & -0.891 & 21.730 & 38.095 \\
Maximum & 9.424 & 3.544 & -0.004 & 29.997 & 105.215 \\
Minimum & -7.357 & -2.036 & -1.917 & 12.577 & 6.251 \\
Std. Dev & 4.044 & 1.700 & 0.663 & 5.298 & 29.160 \\
Skewness & -0.774 & 0.888 & 0.196 & -0.113 & 0.554 \\
Kurtosis & 2.996 & 2.357 & 1.721 & 1.638 & 2.048 \\
Jarque-Bera & 4.791 & 7.133 & 3.580 & 3.815 & 4.271 \\
Probability & 0.091 & 0.028 & 0.167 & 0.148 & 0.118 \\
Observations & 48 & 48 & 48 & 48 & 48
\end{tabular}

Correlation and multicollinearity analysis

$\begin{array}{lcccc}{[1]} & 1.000 & & & \\ {[2]} & 0.168 & 1.000 & & \\ {[3]} & 0.141 & 0.590 & 1.000 & 1.000 \\ {[4]} & 0.297 & 0.677 & 0.656 & -0.127 \\ {[5]} & -0.357 & -0.580 & -0.150 & 2.63 \\ \text { VIF } & & 3.69 & 1.91 & 0.381 \\ \text { Tolerance } & & 0.271 & 0.523 & \end{array}$
0.525 and correlation matrix 
JED

23,2

122

intermediation does not enhance growth in the long run. The negative relationship can be ascribed to the episodes of macroeconomic instability the country encounters. These macroeconomic shocks negatively affect banks' intermediation activities. For instance, in a volatile economy, bank deposits growth declines, which reduces banks' vaults, and thus less funds are available for channeling into productive sectors through lending. The negative finding contradicts the presumptions of the supply-leading hypothesis.

Financial openness indicates a positive significant effect on economic growth. This suggests that openness to the global capital market is imperative for growth in the long run. Liberalizing the financial sector enhances competition in the domestic market, which contributes to stability as postulated by the "competition-stability hypothesis." The hypothesis infers that competition in the domestic banking sector spurs demand for bank credit as banks tend to offer lower interest rates on borrowing. In this case, banks lend to productive sectors and thus enhance output. Our finding conforms to prior studies (Edwards, 2001; Oyovwi and Eshenake, 2013).

Gross fixed capital formation positively affects economic growth albeit insignificantly. This implies that an increase in domestic investment enhances domestic output. Although the effect is insignificant, our result corroborates with the findings of Bakare (2011) and Kanu and Ozurumba (2014).

\begin{tabular}{lcccc}
\hline & \multicolumn{2}{c}{ ADF } & & PP \\
Variables & $t$-statistics & Order & $t$-statistics & Order \\
\hline GDPG & $-6.565^{* * *}$ & $\mathrm{I}(0)$ & $-6.566^{* * * *}$ & $\mathrm{I}(0)$ \\
FINT & $-7.070^{* * *}$ & $\mathrm{I}(1)$ & $-7.180^{* * *}$ & $\mathrm{I}(1)$ \\
FOP & $-7.282^{* * *}$ & $\mathrm{I}(1)$ & $-7.307^{* * *}$ & $\mathrm{I}(1)$ \\
GFCF & $-6.378^{* * *}$ & $\mathrm{I}(1)$ & $-6.684^{* * * *}$ & $\mathrm{I}(1)$ \\
INF & $-7.336^{* * *}$ & $\mathrm{I}(1)$ & $-7.383^{* * *}$ & $\mathrm{I}(1)$ \\
Note(s): $* * *$ denotes stationary at $1 \%$ significance level & & \\
\hline
\end{tabular}

Table 2.

Unit root test

Note(s): ***denotes stationary at $1 \%$ significance level

\begin{tabular}{llrrr}
\hline Test Statistics & Value & Level & \multicolumn{2}{c}{ Critical values } \\
\hline & & & $I(0)$ & $I(1)$ \\
$F$-Statistics & $6.300^{* * * *}$ & $10 \%$ & 2.20 & 3.09 \\
$k$ & 4 & $5 \%$ & 2.56 & 3.49 \\
& & $1 \%$ & 3.29 & 4.37
\end{tabular}

Note(s): $k$ is the number of the explanatory variables and $* * *$ denotes $1 \%$ level of significance

Bounds test for cointegration relationship

Note(s): $k$ is the number of the explanatory variables and "sing

\begin{tabular}{|c|c|c|c|c|}
\hline $\begin{array}{l}\text { ARDL }(4,2,4,4,4) \\
\text { Variable }\end{array}$ & Coefficient & Std. Error & $\begin{array}{c}\text { Model selection method: AIC } \\
t \text {-Statistic }\end{array}$ & Prob. Value \\
\hline \multicolumn{5}{|l|}{ Long-run estimates } \\
\hline $\mathrm{FINT}_{t}$ & -0.963 & 0.386 & -2.493 & $0.021^{* *}$ \\
\hline $\mathrm{FOP}_{t}$ & 2.041 & 0.764 & 2.672 & $0.014 * *$ \\
\hline $\mathrm{GFCF}_{t}$ & 0.092 & 0.113 & 0.812 & 0.426 \\
\hline $\mathrm{INF}_{t}$ & -0.060 & 0.018 & -3.377 & $0.003 * * *$ \\
\hline Constant & 4.768 & 2.750 & 1.734 & $0.098^{*}$ \\
\hline \multicolumn{5}{|c|}{$\operatorname{Note}(\mathbf{s}): * * * * *$ and $*$ denote significance at the 1,5 and $10 \%$ levels, respectively } \\
\hline
\end{tabular}


Consistent with our hypothesis and Fischer (1993), the result evidences a negative significant impact of inflation on economic growth. As inflation magnifies, growth is inhibited. Domestic macroeconomic instability deters investors from committing their investable funds in the domestic market given the surrounded uncertainties. Also, in periods of high inflation, investable resources are diverted to consumption, contributing to low domestic output.

\subsection{Short-run estimation}

Table 5 contains the short-run estimates of our variables. The coefficient of the error correction term of -1.830 is significant at $1 \%$ level. This shows a high convergence rate to the equilibrium and implies that the disturbance in our model reduces by $183 \%$ annually toward the equilibrium. The adjusted $R^{2}$ value of $90.8 \%$ indicates that our included factors largely predict economic growth.

In the short run, financial intermediation positively and significantly drives economic growth supporting the supply-leading hypothesis. This suggests that the financial sector in Turkey particularly banks in the short run can absorb shocks from the macroeconomic environment and can efficiently carry out their intermediation activities. Our short-run finding is similar to most prior studies (Ventura, 2008; Murty et al., 2012; Sahoo, 2014; Türsoy and Faisal, 2018). Contrary to the long run, financial openness exhibits a negative insignificant effect on economic growth. This indicates that financial sector liberalization does not matter for growth in the short run. Consistent with the long-run finding, gross fixed capital formation exerts a positive significant effect on economic growth in the short run indicating the relevance of domestic investment on output growth in Turkey. Likewise, inflation in the short run is detrimental to economic growth, which conforms to the long-run result.

\subsection{Diagnostic tests results}

From the results of the diagnostic tests in Table 6, we can infer that there are no serial correlation and heteroscedasticity issues in our model. The Jarque-Bera test and the Ramsey RESET also signify normal distribution and no functional form misspecification, respectively.

The CUSUM and CUSUM of square plots in Figure 1 and Figure 2 respectively confirm the stability of our estimated model given that at $5 \%$ significance level the CUSUM lines are within the critical boundaries.

\begin{tabular}{lrccc}
\hline ARDL $(4,2,4,4,4)$ & & \multicolumn{3}{c}{ Model selection method: AIC } \\
Variable & Coefficient & Std. Error & $t$-Statistic & Prob. Value \\
\hline$\Delta \mathrm{GDPG}_{t-3}$ & 0.184 & 0.086 & 2.127 & $0.045^{* *}$ \\
$\Delta \mathrm{FINT}_{t-1}$ & 2.100 & 0.851 & 2.468 & $0.022^{* *}$ \\
$\Delta \mathrm{FOP}_{t-3}$ & -1.303 & 1.027 & -1.269 & 0.218 \\
$\Delta \mathrm{GFCF}_{t-3}$ & 0.750 & 0.225 & 3.335 & $0.003^{* * *}$ \\
$\Delta \mathrm{INF}_{t-3}$ & -0.062 & 0.023 & -2.633 & $0.016^{* *}$ \\
$\mathrm{ECT}_{t-1}$ & -1.830 & 0.268 & -6.841 & $0.000^{* * *}$ \\
$R^{2}$ & 0.944 & & & \\
Adjusted $R^{2}$ & 0.908 & & & \\
Durbin-Watson stat & 2.101 & & & \\
$F$-Statistic & 7.877 & & & \\
Prob. $F$-Statistic) & 0.000 & & & \\
Note & & & &
\end{tabular}

Note(s): $* * *, * *$ and $*$ denote significance at the 1,5 and $10 \%$ levels, respectively

\section{Impact of financial intermediation}


JED

23,2

124

Table 6.

Diagnostic tests

\section{Conclusion and recommendations}

In the endogenous growth literature, economic growth is significantly motivated by financial intermediation. For the literature on banking crisis, financial intermediation activities may slow economic growth particularly in episodes of financial crises. This study assesses the impact of financial intermediation on economic growth in Turkey while controlling for the effect of financial openness, gross fixed capital formation and inflation. From the ARDL estimation, the results indicate that financial intermediation significantly affects economic growth. The effect, however, is negative in the long run. Financial openness positively and significantly determines growth only in the long run. Gross fixed capital formation (a measure of domestic investment) positively influences growth though with an insignificant impact in the long run. Inflation generally shows a negative significant effect on economic growth in both periods. This suggests that inflation is detrimental to growth in Turkey.

We present some policy implications in light of our findings. To enhance stability in the financial sector, which affects banks' intermediation activities, the regulatory framework overseeing financial services must be strengthened. The liberalization of the financial sector is essential for sustaining growth. Allowing more banks into the country will increase competition leading to innovation and efficiency of the banking sector, with a consequent effect on the real sector. We recommend that the government must provide incentives for domestic investors to create and boost domestic investments in order to enhance growth. Finally, policymakers must enact workable policies to keep inflation at an optimal level. This will help in improving economic growth in both short and long run.

\begin{tabular}{lcc}
\hline Specification & $F$-statistics & Prob. Value \\
\hline Breusch-Godfrey (Serial Correlation LM test) & 0.478 & 0.627 \\
Breusch-Pagan (Heteroscedasticity) & 0.948 & 0.550 \\
Jarque-Bera (Normality) & 0.181 & 0.914 \\
Ramsey RESET & 0.024 & 0.879 \\
\hline
\end{tabular}

Figure 1.

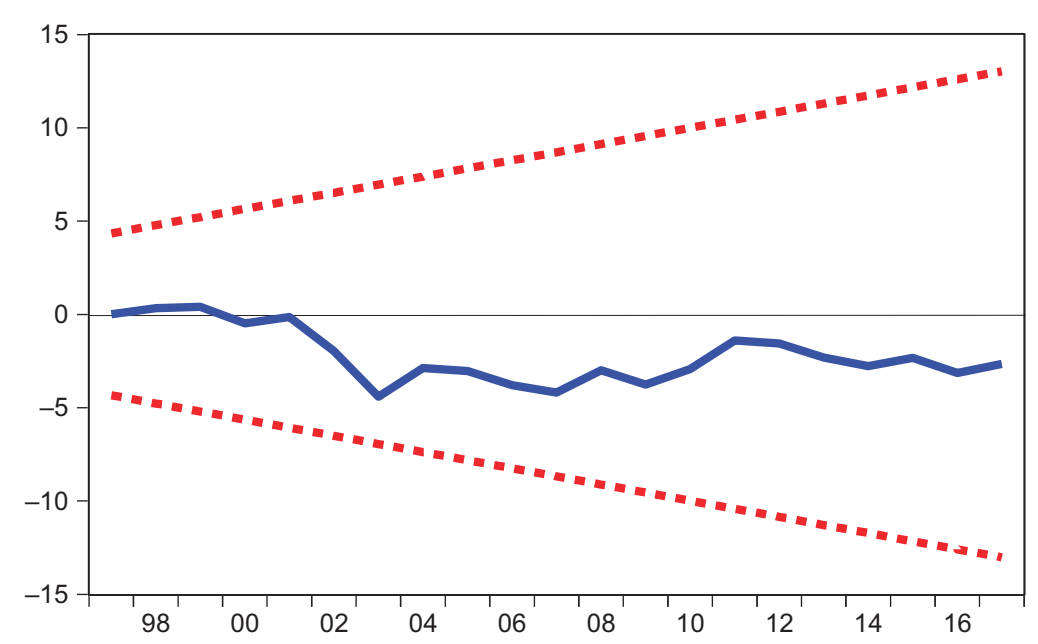

Plots of CUSUM

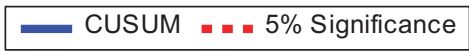



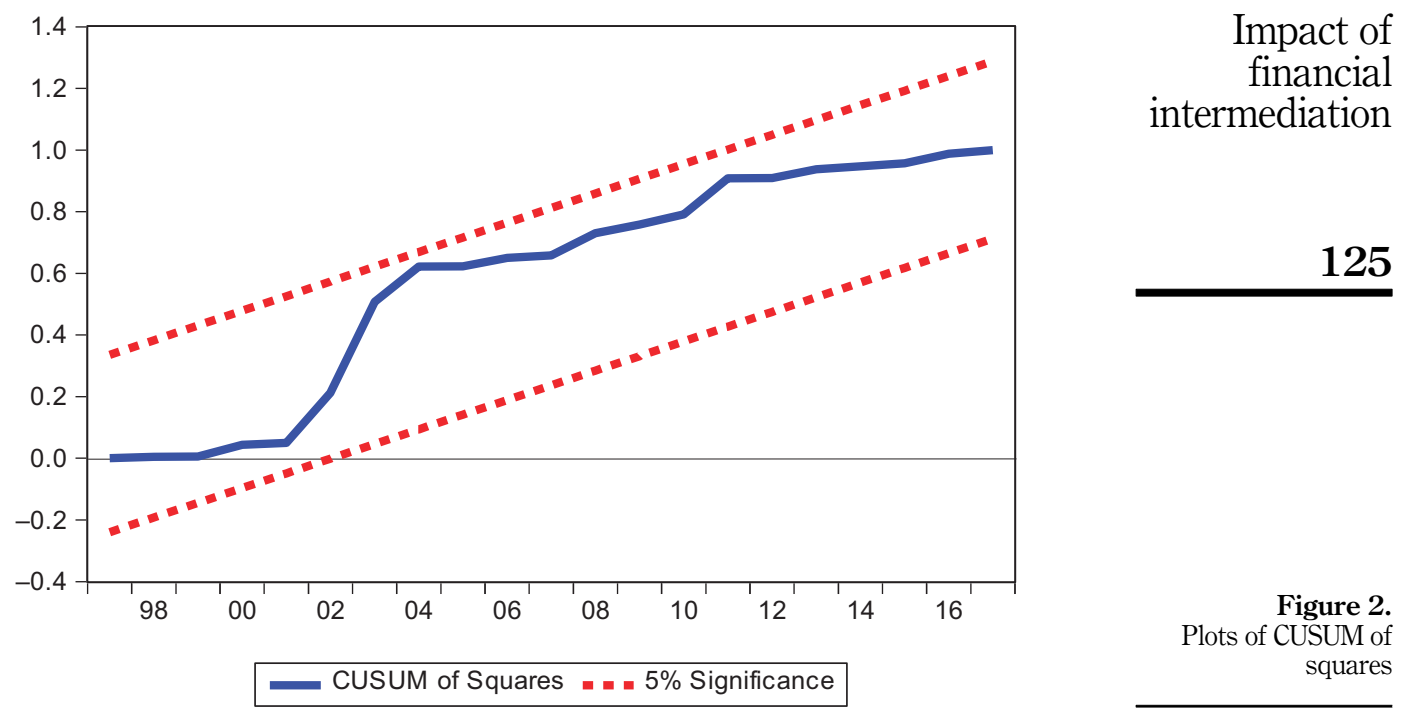

\section{References}

Abdi, H. and Williams, L.J. (2010), "Principal component analysis", Wiley Interdisciplinary Reviews: Computational Statistics, Vol. 2 No. 4, pp. 433-459.

Acha, I.A. (2011), "Does bank financial intermediation cause growth in developing economies: the Nigerian experience", International Business and Management, Vol. 3 No. 1, pp. 156-161.

Adusei, M. and Kofi Afrane, S. (2013), "The Impact of credit union financial intermediation on economic growth: a multi-country analysis", Global Journal of Business Research, Vol. 7 No. 5, pp. 71-78.

Agbada, A.O. and Osuji, C.C. (2013), "An empirical analysis of trends in financial intermediation and output in Nigeria", Global Journal of Management and Business Research, Vol. 13 No. 9, pp. 19-30.

Ak, M.Z., Kirca, M. and Altintaş, N. (2016), "The impacts of financial development on growth: a timevarying causality analysis for Turkey", Zbornik radova Ekonomskog fakulteta u Rijeci: casopis za ekonomsku teoriju i praksu, Vol. 34 No. 2, pp. 529-554.

Amaira, B. and Amairya, R. (2014), "Financial intermediation and economic growth in Tunisia: an econometric investigation”, International Journal of Business and Behavioral Sciences, Vol. 4 No. 3, pp. 1-19.

Atindéhou, R.B., Gueyie, J.P. and Amenounve, E.K. (2005), "Financial intermediation and economic growth: evidence from Western Africa”, Applied Financial Economics, Vol. 15 No. 11, pp. $777-790$.

Aziakpono, M. (2005), "Financial development and economic growth in Southern Africa", Reducing Capital Cost in Southern Africa, Vol. 1 No. 1, pp. 137-167.

Bakare, A.S. (2011), "A theoretical analysis of capital formation and growth in Nigeria", Far East Journal of Psychology and Business, Vol. 3 No. 2, pp. 11-24.

Bogdan, D.I.M.A. and Opriș, P.E. (2013), "Financial intermediation and economic growth", Timisoara Journal of Economics and Business, Vol. 6 No. 20, pp. 127-136.

Demetriades, P.O. and Hussein, K.A. (1996), "Does financial development cause economic growth? Time-series evidence from 16 countries", Journal of Development Economics, Vol. 51 No. 2, pp. 387-411. 
JED

23,2

Demirhan, E., Aydemir, O. and Inkaya, A. (2011), "The direction of causality between financial development and economic growth: evidence from Turkey", International Journal of Management, Vol. 28 No. 1, pp. 3-19.

Edwards, S. (2001), “Capital mobility and economic performance: are emerging economies different?”, Working Paper No. 8076, National Bureau of Economic Research, Massachusetts Avenue, Cambridge, MA.

Estrada, G.B., Park, D. and Ramayandi, A. (2015), "Financial development, financial openness, and economic growth", Working Paper No. 442, Asian Development Bank Economics, Mandaluyong City, Philippines.

Fischer, S. (1993), "The role of macroeconomic factors in growth", Journal of Monetary Economics, Vol. 32 No. 3, pp. 485-512.

Greenwood, J. and Jovanovic, B. (1990), "Financial development, growth, and the distribution of income”, Journal of Political Economy, Vol. 98 No. 5, pp. 1076-1107.

Hardle, W.K. and Simar, L. (2015), Canonical Correlation Analysis, Heidelberg, Berlin.

Hurlin, C. and Venet, B. (2008), "Financial development and growth: a re-examination using a panel Granger causality test”, HAL Working Papers, available at: https://halshs.archives-ouvertes.fr/ halshs-00319995/.

John, E.I. and Nwekemezie, O.A. (2019), "Effect of financial intermediation on economic development of Nigeria", IOSR Journal of Economics and Finance, Vol. 10 No. 1, pp. 23-32.

Jolliffe, I.T. (2002), Principal Component Analysis, Springer-Verlag, New York, NY.

Kanu, S.I. and Ozurumba, B.A. (2014), "Capital formation and economic growth in Nigeria", Global Journal of Human-Social Science: Economics, Vol. 14 No. 4, pp. 43-58.

Kapusuzoglu, A. (2013), "Financial development and economic growth in Turkey: an empirical analysis", Actual Problems of Economics, Vol. 139 No. 1, pp. 314-324.

Kar, M., Peker, O. and Kaplan, M. (2008), "Trade liberalization, financial development and economic growth in the long term: the case of Turkey", South East European Journal of Economics and Business, Vol. 3 No. 2, pp. 25-38.

Kennedy, P. (2003), A Guide to Econometrics, MIT press, Cambridge, MA.

King, R.G. and Levine, R. (1993), "Finance and growth: schumpeter might be right", The Quarterly Journal of Economics, Vol. 108 No. 3, pp. 717-737.

Levine, R., Loayza, N. and Beck, T. (2000), "Financial intermediation and growth: causality and causes", Journal of Monetary Economics, Vol. 46 No. 1, pp. 31-77.

McKinnon, R.I. (1973), Money and Capital in Economic Development, Brookings Institution Press, Washington, DC.

Murty, K.S., Sailaja, K. and Demissie, W.M. (2012), "The long-run impact of Bank credit on economic growth in Ethiopia: evidence from the Johansen's multivariate Cointegration approach", European Journal of Business and Management, Vol. 4 No. 14, pp. 20-33.

Ncanywa, T. and Makhenyane, L. (2016), "Can investment activities in the form of Capital Formation influence economic growth in South Africa?", South African Association of Public Administration and Management, SAAPAM Chapter 5th Annual Conference Proceedings, South Africa, pp. 270-279.

Oyovwi, O.D. and Eshenake, S.J. (2013), "Financial openness and economic growth in Nigeria: a vector error correction approach", African Research Review, Vol. 7 No. 4, pp. 79-92.

Patrick, H.T. (1966), "Financial development and economic growth in underdeveloped countries", Economic Development and Cultural Change, Vol. 14 No. 2, pp. 174-189.

Pesaran, M.H. and Shin, Y. (1998), "An autoregressive distributed-lag modelling approach to cointegration analysis", Econometric Society Monographs, Vol. 31, pp. 371-413.

Pesaran, M.H., Shin, Y. and Smith, R.J. (2001), "Bounds testing approaches to the analysis of level relationships", Journal of Applied Econometrics, Vol. 16 No. 3, pp. 289-326. 
Sahoo, S. (2014), "Financial intermediation and growth: bank-based versus market-based systems", Margin: The Journal of Applied Economic Research, Vol. 8 No. 2, pp. 93-114.

Sharma, S. (1996), Applied Multivariate Techniques, Wiley, New York, NY.

Shaw, E.S. (1973), Financial Deepening in Economic Development, Oxford University Press, New York.

Sulaiman, L.A. and Aluko, O.A.N. (2015), "Financial intermediation and economic growth: a test for causality in Nigeria", Banks and Bank System, Vol. 10 No. 4, pp. 69-74.

Tobin, J. (1965), "Money and economic growth", Econometrica: Journal of the Econometric Society, Vol. 33 No. 4, pp. $671-684$.

Türsoy, T. and Faisal, F. (2018), "Does financial depth impact economic growth in North Cyprus?", Financial Innovation, Vol. 4 No. 1, pp. 1-13.

Ünvan, Y.A. and Yakubu, I.N. (2020), "Do bank-specific factors drive bank deposits in Ghana?", Journal of Computational and Applied Mathematics, Vol. 376, pp. 1-7.

Ventura, C.M. (2008), "The effects of financial intermediation on Colombian economic growth", Ensayos sobre Politíca Económica, Vol. 26 No. 57, pp. 250-281.

Yucel, F. (2009), "Causal relationships between financial development, trade openness and economic growth: the case of Turkey", Journal of Social Sciences, Vol. 5 No. 1, pp. 33-42.

Zaghdoudi, T., Ochi, A. and Soltani, H. (2013), "Banking intermediation and economic growth: some evidence from MENA countries", Advances in Management and Applied Economics, Vol. 3 No. 4, pp. 51-57.

\section{Further reading}

Seven, Ü. and Yetkiner, H. (2016), "Financial intermediation and economic growth: does income matter?", Economic Systems, Vol. 40 No. 1, pp. 39-58.

\section{Corresponding author}

Ibrahim Nandom Yakubu can be contacted at: kassiibrahim@gmail.com

For instructions on how to order reprints of this article, please visit our website:

www.emeraldgrouppublishing.com/licensing/reprints.htm

Or contact us for further details: permissions@emeraldinsight.com 